\title{
Evidence of Early Protein Synthesis Essential to the Spore Germination of Colletotrichum lagenarium
}

\author{
By IWAO FURUSAWA, MASAMICHI NISHIGUCHI, \\ MACHIKO TANI AND NORIO ISHIDA \\ Laboratory of Plant Pathology, Faculty of Agriculture, Kyoto University, \\ Kyoto, Japan
}

(Received II January 1977; revised 7 April 1977)

The biochemical events of spore germination of Colletotrichum lagenarium were investigated. Cycloheximide $(3.55 \mu \mathrm{M})$ inhibited spore germination when added during the first $40 \mathrm{~min}$ of incubation, but was ineffective when added after $40 \mathrm{~min}$. Spores germinated when cycloheximide was removed from the suspension for $2 \mathrm{~h}$ during incubation, regardless of the length of pretreatment with cycloheximide. By pulse-labelling with $\left[{ }^{14} \mathrm{C}\right] \mathrm{glycine}$, it was evident that the protein which was synthesized during the first $40 \mathrm{~min}$ of incubation was indispensable for the initiation of germination, but protein synthesis which occurred at a later stage of incubation was not necessary for spore germination directly.

\section{INTRODUCTION}

It is generally accepted that synthesis of RNA and protein is essential for fungal spore germination. RNA synthesis during spore germination has been reported in Aspergillus niger (Yanagita, 1958), Uromyces phaseoli (Ramakrishnan \& Staples, 1970) and Rhizopus stolonifer (Van Etten, Bulla \& Julian, 1974). In Botryodiplodia theobromae (Bramble \& Van Etten, 1970), protein synthesis was required for spore germination and the spore contained mRNA which was translated immediately after the onset of germination. Dunkle, Maheshwari \& Allen (1969) investigated the relationship between nucleic acid and protein and morphological differentiation in uredospores of Puccinia graminis, and found that de novo protein synthesis was required for germination. In Peronospora tabacina, Holloman (1969) found that stable mRNA was present in the dormant spore and that the protein synthesis which was induced during the first 30 min of incubation was necessary for conidial germination. In this paper, we have studied protein synthesis during the early stage of spore germination of Colletotrichum lagenarium, the usual agent of anthracnose of cucumber, which penetrates intact host tissue by appressoria which are formed at the tip of the germ tube.

\section{METHODS}

Organism. Colletotrichum lagenarium (Pass.) Ellis and Halsted, No. IO4-T, was cultured on potato/sucrose/ agar medium ( $200 \mathrm{~g}$ ground potato, $20 \mathrm{~g}$ sucrose, $30 \mathrm{~g}$ agar and 11 tap water) at $24{ }^{\circ} \mathrm{C}$ for 7 days. Spores on the mycelial mat were collected with a brush and washed three times by centrifuging with ice-cold distilled water to prevent germination.

Spore germination. The spores were suspended in deionized, sterilized water to give about $1 \times 10^{5}$ spores $\mathrm{ml}^{-1}$. A drop of the spore suspension was placed on a glass slide in a humid Petri dish at $24{ }^{\circ} \mathrm{C}$. For each test, 500 spores were counted and those which had germinated were scored.

Inhibitor treatment during spore germination. To examine the significance of protein synthesis during spore germination, water in the spore suspension was removed with the edge of a filter paper after various periods of incubation and a solution of 3.55 $\mu \mathrm{M}$-cycloheximide (Shionogi Pharmacological Industry, Osaka, Japan) was added. Incubation was continued until $23 \mathrm{~h}$ after the start of the experiment. 
To examine the timing of protein synthesis which could be critical to spore germination, $3.55 \mu \mathrm{M}$-cycloheximide was added to the spore suspension and incubated for $I h$. The cycloheximide was then washed out by removing the aqueous solution with the edge of a filter paper and dropping fresh distilled water on to the spores; washing was repeated several times. The spore suspension was incubated for another 10, 30, 60 or I $20 \mathrm{~min}$ in distilled water and then cycloheximide solution was added again. Incubation was continued until $23 \mathrm{~h}$ after the start of the experiment. We called such a series 'intermittent treatment'.

Radioisotope incorporation. Spore suspension $\left(2 \mathrm{ml}, 5 \times 10^{5}\right.$ spores $\left.\mathrm{ml}^{-1}\right)$ was poured into a Petri dish of $4.5 \mathrm{~cm}$ diameter. Tween $20(0.0 \mathrm{I} \%, \mathrm{v} / \mathrm{v})$ and chloramphenicol $(0.3 \mathrm{~mm})$ (both final concentration) were added to disperse the spores and repress bacterial growth, respectively. Preliminary experiments showed that neither Tween 20 nor chloramphenicol had any influence on spore germination at these concentrations. After various periods of incubation $\left[{ }^{14} \mathrm{C}\right]$ glycine (final activity $0.025 \mu \mathrm{Ci} \mathrm{ml}^{-1}$, The Radiochemical Centre, Japan) was added and the reaction mixture was incubated for $5 \mathrm{~min}$. Incorporation was then stopped by addition of $0.35 \mathrm{ml} 30 \%(\mathrm{w} / \mathrm{v})$ trichloroacetic acid (TCA). The Petri dish was placed on ice immediately. Two hours later, acid-insoluble material in the spores was collected on a Millipore filter (SMWPO 2500) and washed with $5 \%$ TCA several times. The filter was dried at $40{ }^{\circ} \mathrm{C}$ for $16 \mathrm{~h}$. The radioactivity was determined with a Horiba LS liquid scintillation counter after adding a toluene-based scintillation fluid containing $4 \mathrm{~g}$ 2,5-diphenyloxazole and $0.3 \mathrm{~g}$ I,4-di-2-(4-methyl-5-phenyloxazolyl)benzene per litre.

\section{RESULTS AND DISCUSSION}

When $3.55 \mu \mathrm{M}$-cycloheximide was added to the spore suspension from the onset of incubation, spore germination was almost completely inhibited (Table I, Expt I). However, germination was not affected when cycloheximide was added $40 \mathrm{~min}$ after the start of incubation. These results suggested that protein synthesis during the first $40 \mathrm{~min}$ of incubation was essential for spore germination. Hollomon (1969) obtained a similar result in that only I I $0 \%$ of spores of Peronospora tabacina germinated if treated with $2 \mu \mathrm{M}$-cycloheximide during the first 20 min of incubation, whereas $89.5 \%$ of spores germinated if treated with cycloheximide after $40 \mathrm{~min}$ incubation.

To elucidate the timing of protein synthesis necessary for spore germination in more detail, the following experiment was carried out. Spore suspension was treated intermittently' with $3.55 \mu \mathrm{M}$-cycloheximide as detailed in Methods, i.e. with an intermission in cycloheximide treatment after the first hour of incubation. Germination was inhibited after a 30 min intermission but not after a 60 min intermission (Table I, Expt 2).

We then examined the effect of a $2 \mathrm{~h}$ intermission in cycloheximide treatment on spores pretreated with $3.55 \mu \mathrm{M}$-cycloheximide for I, 2, 3, 4 or $24 \mathrm{~h}$. The pretreated spores were incubated in water for $2 \mathrm{~h}$, and then incubation was continued with cycloheximide until $23 \mathrm{~h}$ after the start of the experiment (Table I, Expt 3). Although spore germination was slower in the control, the final percentage germination was not affected. Thus a $2 \mathrm{~h}$ intermission was sufficient to allow spores to germinate, regardless of the duration of cycloheximide pretreatment. This result indicates that the action of cycloheximide at this concentration is fungistatic.

The effect of $3.55 \mu \mathrm{M}$-cycloheximide on the incorporation of $\left[{ }^{14} \mathrm{C}\right] \mathrm{glycine}$ into TCAinsoluble material of spores was examined by incubating spores in a Petri dish and pulselabelling with $\left[{ }^{14} \mathrm{C}\right]$ glycine for $5 \mathrm{~min}$ after different periods of incubation (Fig. I). Untreated spores incorporated a large amount of $\left[{ }^{14} \mathrm{C}\right]$ glycine immediately after the start of incubation. The incorporation gradually decreased until $45 \mathrm{~min}$ and then increased again. Mirkes (1974) found that polysome formation was induced by hydration in Neurospora crassa conidia. Our result that a large amount of labelled glycine was incorporated immediately after the start of incubation contrasts with those of Bramble \& Van Etten (1970) and Rousseau \& Halvorson (1973) who reported that the incorporation of labelled protein precursor into the acid-insoluble fraction continuously increased during the early stages of spore germination of Botryodiplodia and Saccharomyces, respectively. Spore germination was repressed when cycloheximide was present from the start of incubation (Table I) and $\left[{ }^{14} \mathrm{C}\right]$ glycine incorporation into acid-insoluble material was almost completely inhibited when cycloheximide was added to the suspension at the start of incubation (Fig. I). 
Table I. Effect of $3.55 \mu \mathrm{M}-$ cycloheximide on spore germination of C. lagenarium

Expt no.

I

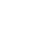$$
\text { treatm }
$$
Intermission $(\mathrm{min})$ after
treatment with cycloheximid

$$
\text { for } I h
$$

$\begin{array}{rr}10 & 2 \cdot 6 \\ 30 & 13 \cdot 8 \\ 60 & 84 \cdot 2 \\ 120 & 92 \cdot 1\end{array}$

3

Time (min) of addition of cycloheximide after start of incubation

$\begin{array}{rr}0 & 0.5 \\ 10 & 11 \cdot 5 \\ 20 & 69 \cdot 5 \\ 40 & 91 \cdot 5 \\ 60 & 92 \cdot 5 \\ 120 & 95 \cdot 4\end{array}$

$23 \mathrm{~h}$

0.5

$69 \cdot 5$

$91 \cdot 5$

$95 \cdot 4$

$2 \cdot 6$

$84 \cdot 2$

$92 \cdot I$

Length of cycloheximide

\section{Percentage}

germination at pretreatment $(\mathrm{h})$

$\begin{array}{rr}\text { I } & 97 \cdot 8 \\ 2 & 90 \cdot 9 \\ 3 & 97 \cdot 8 \\ 4 & 91 \cdot 6 \\ 24 & 94 \cdot 3\end{array}$

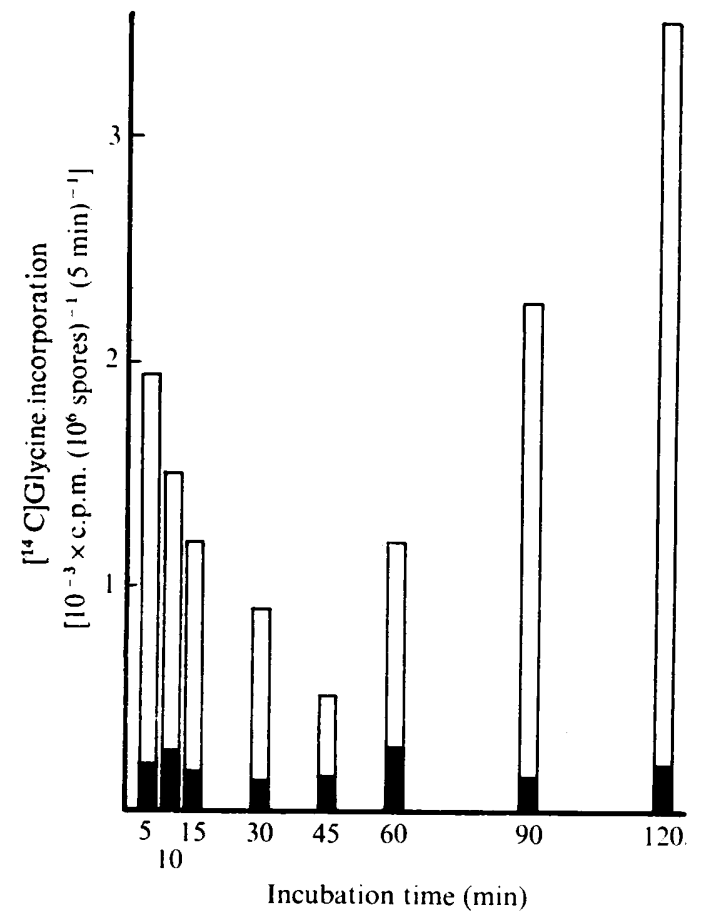

Fig. I. Effect of $3.55 \mu \mathrm{M}$-cycloheximide on the rate of incorporation of $\left[{ }^{14} \mathrm{C}\right]$ glycine into acidinsoluble material during the early stages of germination in $C$. lagenarium. Spores were labelled for $5 \mathrm{~min}$ with $\left[{ }^{14} \mathrm{C}\right] \mathrm{glycine}\left(0.025 \mu \mathrm{Ci} \mathrm{ml}{ }^{-1}\right)$ added at $0,5,10,25,40,55,85$ and $115 \mathrm{~min}$ after the start of incubation. Open bars, untreated; black bars, treated with $3.55 \mu \mathrm{M}$-cycloheximide from the onset of incubation. 
Table 2. Effect of $\mathrm{I} \cdot 77 \mu \mathrm{M}$-cycloheximide on the rate of incorporation of $\left[{ }^{14} \mathrm{C}\right]$ glycine into acid-insoluble material during the early stage of germination of C. lagenarium

\begin{tabular}{|c|c|c|c|}
\hline \multirow{2}{*}{$\begin{array}{l}\text { Time after } \\
\text { onset of } \\
\text { incubation } \\
\text { (min) }\end{array}$} & \multicolumn{2}{|c|}{$\begin{array}{l}\text { Radioactivity incorporated } \\
\left(\% \text { of control }{ }^{*}\right)\end{array}$} & \multirow[b]{2}{*}{$\begin{array}{c}\text { Control incorporation } \\
{\left[10^{-3} \times \text { c.p.m. }\left(10^{6} \text { spores }\right)^{-1}(5 \mathrm{~min})^{-1}\right]}\end{array}$} \\
\hline & $\begin{array}{l}\text { Treated with Cyc } \\
\text { after } 60 \mathrm{~min}\end{array}$ & $\begin{array}{l}\text { Treated with Cyc } \\
\text { from onset }\end{array}$ & \\
\hline 20 & - & $17 \cdot 4$ & $2 \cdot 032$ \\
\hline 80 & $17 \cdot 6$ & $14 \cdot \mathrm{I}$ & I. 540 \\
\hline 180 & $27 \cdot 2$ & $26 \cdot 0$ & 3.849 \\
\hline 360 & $19 \cdot 0$ & 19.0 & 2.965 \\
\hline
\end{tabular}

Cyc, Cycloheximide.

* Spores were pulse-labelled for $5 \mathrm{~min}$ with $\left[{ }^{14} \mathrm{C}\right]$ glycine $\left(0.025 \mu \mathrm{Ci} \mathrm{ml}^{-1}\right)$ added at $15,75,175$ and 355 min from the start of the experiment.

Another experiment using the pulse-labelling technique was carried out to confirm the importance of early protein synthesis to spore germination. Preliminary experiments showed that $\mathrm{I} \cdot 77 \mu \mathrm{M}$-cycloheximide treatment in a Petri dish gave the same results as $3.55 \mu \mathrm{M}$ cycloheximide treatment on a glass slide. Pulse-labelling was carried out with $\left[{ }^{14} \mathrm{C}\right]$ glycine for $5 \mathrm{~min}$ after different periods of incubation, using spores treated with $\mathrm{I} \cdot 77 \mu \mathrm{M}$-cycloheximide from the start of incubation or from 60 min after the start of incubation. When the spores were treated with cycloheximide from the start of incubation, the incorporation of labelled glycine was inhibited by about $80 \%$ compared with that in untreated spores. However, the percentage germination after $23 \mathrm{~h}$ was $0.6 \%$ and $99.7 \%$, respectively. Once early protein synthesis had occurred the majority of spores germinated, even if protein synthesis which took place after $60 \mathrm{~min}$ was considerably inhibited (Table 2). Therefore, it is suggested that early protein synthesis in spore germination is important as a possible initiation factor of germination.

The authors wish to acknowledge the helpful advice of Dr H. Kunoh and Dr S. Mayama.

\section{REFERENCES}

Bramble, R. M. \& VAN EtTen, J. L. (1970). Protein synthesis during fungal spore germination. V. Evidence that the ungerminated conidiospores of Botryodiplodia theobromae contain messenger ribonucleic acid. Archives of Biochemistry and Biophysics 137, 442-452.

Dunkle, L. D., Maheshwari, R. \& Allen, P. J. (1969). Infection structures from rust uredospores: effect of RNA and protein synthesis inhibitors. Science 163, 481-482.

Hollomon, D. W. (1969). Biochemistry of germination in Peronospora tabacina (Adam) conidia: evidence for the existence of stable messenger RNA. Journal of General Microbiology 55, 267274.

MIRKES, P. E. (I974). Polysomes, ribonucleic acid, and protein synthesis during germination of
Neurospora crassa conidia. Journal of Bacteriology II7, 196-202.

RAMAKRISHNAN, L. \& Staples, R. C. (1970). Changes in ribonucleic acids during uredospore differentiation. Phytopathology 60, 1087-1097.

Rousseau, P. \& Halvorson, H. O. (I973). Macromolecular synthesis during the germination of Saccharomyces cerevisiae spores. Journal of Bacteriology 113, 1289-1 295.

VAN EtTen, J. L., Bulla JR, L. A. \& Julian, G. (1974). Physiological and morphological correlation of Rhizopus stolonifer spore germination. Journal of Bacteriology Ir7, 882-887.

YANAGITA, T. (1958). Biochemical aspects on the germination of conidia spores of Aspergillus niger spores. Annual Report of the Institute of Food Microbiology 11, 34-45. 